\title{
The Reflection of Tepa Selira 'Considerate' in the Provincial Parliament's Meeting of Yogyakarta Special Territory
}

\author{
Dwi Santoso, Ph.D
}

\begin{abstract}
This study is generally to seek the reflection of tepa selira 'considerate or position oneself at the place of the addressee or acting towards others as you would have them act toward you' in the dialogues used by the participants attending the Rapat Kerja 'Working Meeting' of the Yogyakarta's Provincial Parliament. The subjects of this study are all the participants attending the Rapat Kerja in a certain period. Play back interviews have been mainly used to seek the reflection of tepa selira. Besides, passive participatory, video recordings, and field note are conducted. The analysis shows that the reflection of tepa selira has been seen in the utterances spoken by the Chair as the one with the highest position when expressing krámá inggil 'a high level of Javanese', code switching, polite greeting and addressing so as to create rukun 'social harmony' and avoid conflicts.
\end{abstract}

\section{INTRODUCTION}

It is known that Yogyakarta is one of the provinces in Indonesia in which the people tend to speak politely. This phenomenon might occur as there are Javanese values guiding the way they use the language. The younger people tend to be andhap asor ,to position oneself in the low and humble position " when they speak to the older one. Conversely, the older tend to be tepa selira ,considerate or position oneself at the place of the addressee or acting towards others as you would have them act toward you". These practices seem to have been regularly used by the people of Yogyakarta, applying the language considered polite so as to create rukun ,social harmony", such as: using krámá inggil „high level of Javanese ee, code switching, indirect strategies, etc. Failing to do so, they will be considered saru ,rude"

In this study, the writer tries to investigate whether or not there are practices of tepa selira reflected in the dialogues used by the participants attending the Provincial Parliament"s Meeting of Yogyakarta Special Territory so as to create rukun and avoid conflicts among the participants attending the meeting. The writer focuses on the dialogues used in the Rapat Kerja „Working Meetinge due to the various participants attending the meeting, such as: executives, legislatives, judicative, etc.

\section{RELATED THEORIES}

\subsection{Tepa Selira 'Considerate or to Position Oneself at the Place of the Addressee'}

The Javanese principle tepa selira has normally been applied by the Javanese speaker to show his sympathy or solidarity to the interlocutors with the intention that rukun can be achieved (Wolff \& Poedjosoedarmo, 1982). In practicing tepa selira, Poedjosoedarmo (2009) suggests that the speaker, regardless of the position, is expected to choose the language or the speech level that can be understood by the interlocutors. If the interlocutors are not good at Indonesian, the speaker should not use Indonesian. If the interlocutors are not good at using krámá inggil, the speaker should apply madyá (middle, moderate) level. In short, the speaker should be bermomot, accomodative ee to establish a smooth communication. Following Gunarwan"s (1996) idea, Iragiliati (2005:180) argues that tepa selira has "The sub-maxims related to the language use: (1) use appropriate language when addressing others as you also want others to use appropriate language in addressing you, and (2) avoid using inappropriate language (including the speech level) as you don"t want others to apply the wrong language forms when addressing you".

Likewise, Kartomihardjo (1981) maintains that tepa selira, whose value is expressed by the cliché tepakno awakmu dhewe (treat him as if he were you), has been one of the Javanese basic principles to establish rukun. In pratice, if the speaker treats the interlocutors in a particular way, they will treat 
him in the same way. In other words, if the speaker is good with the interlocutors, he will also have the same treatment from the interlocutors.

\subsection{Rukun 'Social Harmony'}

Rukun is the model situation that can create peace without quarrel or dispute. Guinness (1986) adopting Geertz's (1961) idea describes rukun as the situation based on the Javanese view in which emotion that might trigger conflict should be highly controlled by the members of society. The characteristics of this principle are cooperation, mutual acceptance, calmness, and unity. When the speaker is speaking to the hearer, the speaker is expected to speak calmly and emotionlessly. If the speaker does not agree with the hearer, the speaker will not say so directly. Instead, the speaker will use special answers that are thought to be polite to Javanese and are effective in mitigating the face threatening acts, such as menawi pemanggih kula ( according to me), or menapa saenipun mboten mekaten (wouldnet it be better if...). The speaker applies this to avoid any conflict and confrontation with the hearer.

\section{METhOD}

\subsection{Subjects}

Since the data used in this study have been limited to the interaction conducted in the Rapat Kerja of Yogyakarta"s Provincial Parliament from September 2012 to January 2014. The subjects of the study have been selected from all the participants generally attending the Rapat Kerja „Working Meetingee in that period. They are the 55 active MPs (including the Chairs) of Yogyakarta"s Provincial Parliament from 2009-2014 periods

\subsection{Investigative Instruments}

In collecting the data from the Rapat Kerja sessions of the Provincial Parliament of Yogyakarta from September 2012 to January 2014, I have applied a triangulation approach to data collection, which includes some different techniques of collecting the data: a passive participatory observation, fieldnote, documentation, video recording, and playback interviews. The fundamental reason to apply multiple sources to collect the data is to get rich data and to seek convergence and support for the study. Besides, I try to avoid getting the result which may create potential bias due to the use of a single method and source. As Bowen (2009:28) says:

"By triangulating data, the researcher attempts to provide,,a confluence of evidence that breeds credibility"e (Eisner, 1991, p.110). By examining information collected through different methods, the researcher can corroborate findings across data sets and thus reduce the impact of potential biases that can exist in a single study. According to Patton (1990), triangulation helps the researcher guard against the accusation that a study"s findings are simply an artefact of a single method, a single source, or a single investigator"s bias".

\section{FINDINGS}

In the context of the Provincial Parliament of Yogyakarta, tepa selira has normally been used by the Chair as he/she is empowered with power over the other participants. The following Video Excerpts 1.line 1, 2.line 8-9, 3.line 11-16, and 4.line1-7 display some practices of tepa selira.

Video Excerpt1. The Chair addressing all the participants before the meeting starts

\begin{tabular}{ccll}
\hline Participants & Line & \multicolumn{1}{c}{ (Original Language) } & \multicolumn{1}{c}{ English (Translated) } \\
\hline The Chair & $1 \rightarrow$ & BapakIbu yang kami & /Literally, Father and \\
& $2 \rightarrow$ & $\begin{array}{l}\text { hormati,DenganmengucapBismillahirahmanirrahim, } \\
\text { RapatKerjapadasiang sore hariinikitamulai. }\end{array}$ & $\begin{array}{l}\text { Mother whom we respect/ By } \\
\text { the name of charitable of God }\end{array}$ \\
& 3 & & Almighty Let"s open the \\
& 5 & & RapatKerja. \\
\hline
\end{tabular}

Video Excerpt2. The Chair addressing the MPs

\begin{tabular}{ccll}
\hline Participant & Line & \multicolumn{1}{c}{ (Original Language) } & English (Translated) \\
\hline Iwid & 1 & ...Eesayaberharapesensidariitubisadijadikanacuan. & ... Ee I hope the essence can be \\
(Executive) & 2 & Hanyakarena jam karettadi. & used as a reference. \\
& 3 & Ngihsayapikiritu, & That is only about the time \\
& 4 & $\underline{M} \boldsymbol{M} \boldsymbol{T} \boldsymbol{R} \boldsymbol{N} \boldsymbol{W} \boldsymbol{U} \boldsymbol{N}$ & delayed. \\
& 5 & & Well, I think that is all,
\end{tabular}


The Reflection of Tepa Selira 'Considerate' in the Provincial Parliament's Meeting of Yogyakarta Special Territory

\begin{tabular}{ccll}
\hline The Chair & 6 & & $\underline{\text { THANKS }}$ \\
& $8 \rightarrow$ & NGGIH,Anggota Dewan yang sayahormati, & WELL,The MPs whom I \\
& $9 \rightarrow$ & Jadiinihanya forum penjelasandarieksekutif. & $\begin{array}{l}\text { respect, } \\
\text { So this isjustan explanation } \\
\text { forum ofthe executives. }\end{array}$ \\
\hline
\end{tabular}

Video Excerpt3. An Executive greeting all the participants before delivering information

$\begin{array}{cr}\text { Participant } & \text { Li } \\ \text { The Chair } & 1 \\ & 2 \\ & 3 \\ & 4 \\ 5 \\ 6 \\ 7 \\ 8 \\ 9 \\ 10\end{array}$

Mr.SEKDA 11 12

(Executive)

$$
\begin{aligned}
& 13 \\
& 14 \\
& 15
\end{aligned}
$$$$
16
$$

(Original Language)

...Tapi untuk lebih baiknya, kami Beri kesempatan terlebih dulu kepada Pak SEKDA

Untuk bias menyampaikan seperti yang kami

Sampaikan tadi perkembangan-

Perkembangan berkenaan dengan undangundang keistimewaan. Kami persilahkan.

\section{Assalamu'alaikum warrahmatullahi} wabarakatuh.

Selamat pagi dan salam sejahtera untuk kita semua.
English (Translated) ...But to be good, we give the first opportunity to Mr. SEKDA, to be able to deliver, as we presented them with the developments in the

law related to privilege.

\begin{tabular}{|c|c|c|c|}
\hline Participant & Line & Original & $\begin{array}{c}\text { English } \\
\text { (Transl ated) }\end{array}$ \\
\hline \multirow[t]{7}{*}{ The Chair } & 1 & $\begin{array}{l}\text { Pertama-tama marilah kita sebelumnya memanjatkan } \\
\text { puji dan syukur kehadirat Tuhan }\end{array}$ & $\begin{array}{l}\text { First of all, let us (Incl) pray } \\
\text { to God Almighty }\end{array}$ \\
\hline & 2 & Yang Maha Kuasa, & \\
\hline & 3 & yang & \\
\hline & 4 & $\begin{array}{l}\text { telah menetapkan keselamatan dan kesehatan bagi kita } \\
\text { semua sehingga pada siang hari ini kita }\end{array}$ & $\begin{array}{l}\text { that has given us protection } \\
\text { and health }\end{array}$ \\
\hline & 5 & $\begin{array}{l}\text { dapat melaksanakan agenda Rapat Kerja badan } \\
\text { anggaran bersama dengan pihak } P B\end{array}$ & $\begin{array}{l}\text { so that in this afternoon we } \\
\text { (incl) can carry on the agenda } \\
\text { of the Rapat Kerja to discuss } \\
\text { the budget with PB }\end{array}$ \\
\hline & 6 & dalam rangka untuk harmonisasi... & in order to harmonise... \\
\hline & 7 & $\begin{array}{l}\text { usulan perubahan APBD tahun } 2012 \text { Daerah Istimewa } \\
\text { Yogyakarta. }\end{array}$ & $\begin{array}{l}\text { the proposal of Yogyakarta } \\
\text { Special Territoryes }\end{array}$ \\
\hline
\end{tabular}
We please [Mr.SEKDA].

Video Excerpt4. The Chair granting a praising speech act to start the RapatKerja

It is noted that the Chair"s choice of the addressing speech acts in video excerpt 1-2 has been very much based on the Javanese principle tepa selira.

From the interview, it is noted that the use of polite addressing in Video Excerpt 1 line 1-2: Bapak Ibu yang kami hormati „Literally, Father and Mother whom we respect"e and 2 line 8-9: Nggih, Anggota Dewan yang saya hormati „Well, the MPs whom I respect" have been intentionally conducted by the

Chair so as to show his being tepa selira, respecting the interlocutors of lower position despite the fact 
that he is not obliged to do so. By so doing, he expects that he will be given the same respectful expressions, which can then enhance his integrity. In this regard, Mr.Chair has argued that

When I interact with other people, I always do that in the most polite way regardless of the interlocutors ${ }^{\text {ee }}$ status and position. The same is true when I address the participants in the meeting.

To show my being tepa selira with them, I usually apply the most polite and common term of address, i.e., Bapak Ibu yang kami hormati regardless of their position. By so doing, it will not be only very beneficial for them but also for me as I know that if I give a high respect for them, they will give me a high respect as well. In this, my integrity will be enhanced, and they will give more trust to me. In Java, there is a proverb saying Wong jowo yen dipangku mati" ${ }^{\text {"1 }}$ (Mr.Chair, 18/09/2014, my translation)

Based on the video excerpt 3.line 11-16, it also noted that the Chair has intentionally applied Muslim and Indonesian greeting: Assalamu'alaikum warrahmatullahi wabarakatuh. Selamat pagi dan salam sejahtera bagi kita semua and Indonesian praising Pertama-tama marilah kita sebelumnya memanjatkan puji dan syukur kehadirat Tuhan Yang Maha Kuasa, yang telah menetapkan keselamatan dan kesehatan bagi kita sетиa) and Indonesian praising in the video excerpt 4.line 1-7:

Pertama-tama marilah kita sebelumnya memanjatkan puji dan syukur kehadirat Tuhan Yang Maha Kuasa, yang telah menetapkan keselamatan dan kesehatan bagi kita semua 'First of all, let us (Incl) pray to God Almighty that has given us protection and health ${ }^{\text {ee }}$ so as to show his sympathy to all the interlocutors who has various religions despite the Muslim majority. In that instance, the Chair, who is Muslim, wants to show that he is a wise leader who not only respects the Muslim interlocutors but also the non-ones.

It is also noted that the Chair has practiced a Javanese teaching related to tepa selira: Yen ora gelem dijiwit aja sok njiwiti Wong liya "If you don"t want to be pinched, you are not supposed to pinch someone elsee. This term can implicitly mean that, if you do not want to be hurt by someone, you are not supposed to hurt someone else". With this practice, it is expected that his greeting will not make the interlocutors feel irritated but rather pleased. In return, it is noted that the Chair expects the interlocutors of lower position to give a high respect for him, applying the utterances whose politeness level is at least similar to the one applied by the Chair. In this regard, Mr.Chair has said that

"As a leader in the meeting, I have to be wise in leading the Parliament"s meetings. I know that there are some participants attending the meeting who are not Muslim. Thus, as a Muslim, I do not want to be selfish by applying Arabic greetings to all the participants. Instead, I usually greet them using Arabic and Indonesian greetings to show my being tepa selira „considerate ${ }^{\text {ee }}$ and sympathy to all the participants. As a Javanese, I always practice a Javanese teaching related to tepa selira: Yen ora gelem dijiwit aja sok njiwiti wong liya" (Mr.Chair, 18/09/2014, my translation).

What may be worth mentioning is that the Javanese principle tepa selira has been applied by the Chair not only in greeting and addressing but also to some other speech acts and anyone in the hall without exception as he thinks that it is more profitable for both sides and can actually establish rukun. In this regard, Mr.Chair has said that

"I practice tepa selira principles in most of my communication with all the participants, both formal and informal as I believe that tepa selira is very effective to build effective and efficient communication. The impact is very tremendous to make the discussion run properly, as the participants will be more opened to me. They will give their response more openly because they have to be polite. If they are closed, they will be considered impolite. Thus, they will tend to be more opened to me in giving their information, response and argument" (Mr.Chair, 18/09/2014, my translation)

\footnotetext{
${ }^{1}$ Wong Jowo yen dipangkumati ,literally, Javanese people will be dead if they are supported ${ }^{e}$. This term means that it is expected for the Javanese people to respect others regardless of their status and position, using the most polite way when speaking to give a high value to other ${ }^{\text {ee }}$ feeling. By so doing, it is expected that they (the interlocutors) will be difficult or uneasy to refuse the speaker"es wants, even when they are not interested in the want.
} 
Given the argument, this present study may be comparable to what has been argued by Mulder (2001) claiming that the Javanese principle tepa selira gives a key to the practice and theory of leadership inspired by the Javanese people today. The leadership will feel threatened if s/he does not protect his subordinates. The leader who protects subordinates and subordinates who respect the boss are considered as a very high reflection of tepa selira. Criticism should be done by both sides based on the spirit of introspection. Endraswara (2013) in his book on Falsafah Kepemimpinan Jawa The

Philosophy of Leadership in Java ${ }^{\text {ee }}$ maintains that the leader applying the Javanese principle tepa selira will be wise in his leadership because it will evoke the feelings of awe and compassion, in which the one with higher status should show his sympathy to the one of lower position. Further, he points out that the leaders applying tepa selira will be more introspective and tend to get more respects from the lower. In contrast, the leaders who oppose tepa selira will usually be authoritarian and are likely to get more resistance from the lower and other participants.

\section{Conclusion}

This paper has looked the reflection of tepa selira in the dialogues used by the participants attending the Yogyakarta"es Provincial Parliament Meeting. A comprehensive analysis, which is also based on the playback interview, has shown that tepa selira has generally been applied by the Chair to show his humbleness and to respect the other participants of lower position. Besides, this practice has been intentionally done by the Chair to create rukun and avoid conflicts. The reflection of tepa selira can be seen in the use of polite addressing, greetings and krámá inggil. This finding confirms the truth of the Javanese people who still apply tepa selira as one of their guidance when communicating with the others regardless of the place.

\section{REFERENCES}

Bowen, G. A. (2009). Document analysis as a qualitative research method. Qualitative Research Journal, 9(2), 28-40.

Eisner, E. W. (1991). The enlightened eye: Qualitative inquiry and the enhancement of educational practice. Toronto: Collier Macmillan Canada.

Endraswara, S. (2013). Falsafah kepemimpinan Jawa (1st ed.). Yogyakarta: Narasi.

Geertz, H. (1961). The Javanese family: A study of kinship and socialization. Glencoe,U.S.A: The Free Press.

Guinness, P. (1986). Harmony and hierachy in Javanese Kampung. New York, NY.: Oxford University Press.

Iragiliati, E. (2005). Utterance patterns and politeness strategies in Indonesian medical discourse. Discourse. State University of Malang.

Kartomihardjo, S. (1981). Ethnography of communicative codes in East Java. (W.A.L.Stokhof, Ed.). Canberra: Australian National University.

Mulder, N. (2001). Ideologi kepemimpinan Jawa. In Kepemimpinan Jawa. Jakarta: Yayasan Obor Indonesia.

Patton, M. Q. (1990). (1990). Qualitative evaluation and research method (2nd ed.). Newbury Park,CA: Sage Publication.

Wolff, J. U., \& Poedjosoedarmo, S. (1982). Communicative codes in Central Java. New York, NY.: Cornell University Press.

\section{AUTHOR's BIOGRAPHY}

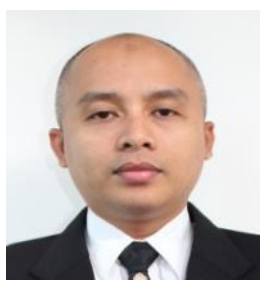

Dwi Santoso, Ph.D. is a senior lecturer on Linguistics at Ahmad Dahlan University Yogyakarta, Indonesia. He finished his undergraduate in English from Ahmad Dahlan University, 1998. He got his master degree in Linguistics from Gadjah Mada University, 2004. His Ph.D. was achieved at La Trobe University Melbourne, 2016 with the special attention to Linguistic Politeness Strategies in Javanese Political Discourse. Santoso is also concerned on Linguistic Forensic, which is about the construction of the language for the justice or law purpose. Most of his studies are closely related to sociolinguistics, psycholinguistics, semantics, and pragmatics. 